\title{
EVALUASI TUTUPAN LAHAN SEBAGAI UPAYA MENGURANGI RESIKO BENCANA LONGSOR DI KECAMATAN KARANGKOBAR KABUPATEN BANJARNEGARA
}

\author{
Oleh: \\ Sakinah Fathrunnadi Shalihati ${ }^{1}$ \\ ${ }^{1}$ Dosen Pendidikan Geografi FKIP Universitas Muhammadiyah Purwokerto \\ JI. Raya Dukuh Waluh PO.BOX. 202 Purwokerto 53182 \\ E-mail: sakinah_fs@yahoo.co.uk / queen.geo85@gmail.com
}

\begin{abstract}
Abstrak
Penelitian ini dilatar belakangi oleh kejadian bencana longsor yang terjadi di Desa Sampang Kecamatan Karangkobar Kabupaten Banjarnegara Propinsi Jawa Tengah tahun lalu tepatnya Bulan Desember 2014. Bencana longsor dapat dipicu oleh aktifitas manusia yang kurang tepat dalam pemanfaatan lahan. Bentuk pengaturan mengenai pemanfaatan lahan Kecamatan Karangkobar telah diatur dalam Rencana Tata Ruang Kabupaten Banjarnegara Tahun 2011-2031. Untuk itu sangat diperlukan evaluasi terhadap tutupan lahan berbasis tata ruang dengan arahan pemanfaatan lahan semestinya, sebagai bentuk pendekatan dalam evaluasi pemanfaatan ruang yang diharapkan segera dilakukan penangan perencanaan dan aplikasi pemanfaatan lahan yang tepat dan berkelanjutan. Tujuan dalam penelitian ini untuk mengetahui distribusi tutupan lahan berbasis tata ruang, distribusi arahan pemanfaatan lahan, evaluasi kesesuaian antara distribusi tutupan lahan berbasis tata ruang dengan arahan pemanfaatan lahan di Kecamatan Karangkobar. Metode penelitian menggunakan analisis data skunder. Unit analisisnya berupa desa-desa di Kecamatan Karangkobar. Teknik analisis kualitatif dengan bantuan software Sistem Informasi Geografi (SIG) untuk analisis peta tutupan lahan berbasis tata ruang, peta arahan pemanfaatan lahan, peta evaluasi kesesuaian tutupan lahan berbasis tata ruang dengan arahan pemanfaatan lahan tiap desa di Kecamatan Karangkobar. Hasil Penelitian menunjukkan bahwa dominasi tutupan lahan berbasis tata ruang desa-desa di Kecamatan Karangkobar tidak sesuai dengan arahan pemanfaatan lahan sebesar 85,38\%. Distribusi tidak sesuai sepenuhnya pada luas wilayah Desa Ambal, Binangun, Jlegong, Karangkobar, Leksana, Slatri. Sedangkan Desa Purwadadi diketahui sesuai 7,15 hektar, tidak sesuai 201,90 hektar, Desa Pasuruhan sesuai 85,09 hektar, tidak sesuai 452,83 hektar, Desa Pawedan sesuai 96,59 hektar, tidak sesuai 374,02 hektar, Desa Pagerpelah sesuai 121,52 hektar, tidak sesuai 338,59 hektar, Desa Sampang sesuai 79,73 hektar, tidak sesuai 220,53 hektar, dan Desa Gumelar sesuai 194,25 hektar, tidak sesuai 125,31 hektar.
\end{abstract}

Kata Kunci: Evaluasi, Tutupan Lahan, Tata Ruang, Arahan Pemanfaatan Lahan, Resiko Bencana Longsor. 
Evaluasi Tutupan Lahan Sebagai Upaya Mengurangi Resiko Bencana Longsor Di Kecamatan Karangkobar Kabupaten Banjarnegara

\section{PENDAHULUAN}

Pada akhir Tahun 2014, Bangsa Indonesia kembali dikejutkan dengan peristiwa bencana longsor yang mengakibatkan banyaknya timbul korban di Desa Sampang Kecamatan Karangkobar Kabupaten Banjarnegara. Kurang lebih 100 orang meninggal akibat bencana tersebut. Bencana longsor pada dasarnya merupakan salah satu bencana yang dapat dihindarkan, yaitu dengan adanya mitigasi bencana longsor. Mitigasi longsor tidak hanya sekedar memberikan penyuluhan kepada masyarakat akan bahaya dan lokasi yang aman dari bencana longsor, namun juga diawali dari merancang tata ruang yang tepat dan sesuai pada lingkungan wilayah tersebut.

Rencana Tata ruang yang diatur oleh pemerintah menjadi landasan bagi masyarakat dalam pemanfaatan lahan atau bentuk tutupan lahan wilayahnya. Jika ketentuan tutupan lahan dalam rencana tata ruang diatur dan ditetapkan tanpa mempertimbangkan arahan pemanfaatan lahan yang tepat maka dapat menimbulkan kerusakan pada lingkungan. Sesuai dengan pernyataan Yani (2007) bahwa arahan pemanfaatan lahan merupakan dasar yang digunakan bagi penentuan dan pengambilan keputusan dalam pengaturan penggunaan lahan serta kebijakan pemanfaatan ruang disuatu wilayah dengan pertimbangan aspek-aspek lainnya seperti sosial dan ekonominya (Suci, 2009).

Menghindari kerusakan lingkungan dalam bentuk bencana longsor yang lebih besar pada dimensi selanjutnya, maka perlu dilakukan evaluasi terhadap tutupan lahan yang telah ditentukan dalam rencana tata tuang dengan arahan pemanfaatan lahan semestinya di wilayah Kecamatan Karangkobar. Sebagai bentuk pendekatan dalam evaluasi pemanfaatan ruang agar segera dilakukan penangan untuk optimalisasi pemanfaatan lahan yang tepat dan berkelanjutan.

1. Berdasarkan pemaparan tersebut, tujuan penelitian ini adalah:

a. Mengetahui distribusi tutupan lahan berbasis tata ruang tiap desa di Kecamatan Karangkobar.

b. Mengetahui distribusi arahan pemanfaatan lahan tiap desa di Kecamatan Karangkobar.

c. Mengetahui evaluasi keselarasan antara tutupan lahan berbasis tata ruang dengan arahan pemanfaatan lahan tiap desa di Kecamatan Karangkobar.

2. Sedangkan manfaat Penelitian untuk memberikan kontribusi nyata dalam:

a. Akademis, yaitu semakin memperkaya pengetahuan dibidang geografi khususnya evaluasi tutupan lahan berbasis tata ruang berdasarkan arahan pemanfaatan lahan dari sudut pandang spasial.

b. Aplikasi Keilmuan, yaitu sebagai pertimbangan kebijakan dalam mengatasi permasalahan keruangan terutama terkait tutupan lahan berbasis tata ruang dan arahan pemanfaatan lahan di Kecamatan Karangkobar, sebagai bentuk kepedulian dalam mengurangi resiko bencana longsor. 


\section{METODE PENELITIAN}

Penelitian ini menggunakan metode data sekunder. Pengelolaan data penelitian didukung menggunakan software SIG. Penggunaan SIG bertujuan untuk diperoleh gambaran secara spasial kondisi tutupan lahan dan arahan pemanfaatan lahan di Kecamatan Karangkobar.

1. Tahap Pengumpulan dan Pengolahan Data

Tahap ini data yang dikumpulkan berupa Peta Tutupan Lahan, Peta Kelerengan, Peta Curah Hujan dan Peta Tanah dari Rencana Tata Ruang Kabupaten Banjarnegara Tahun 2011-2031 yang diperoleh dari Badan Perencanaan dan Pembangunan Daerah (BAPPEDA) Kabupaten Banjarnegara. Keempat peta tersebut dimanfaatkan untuk pembuatan Peta Tutupan Lahan Berbasis Tata Ruang, Peta Arahan Pemanfaatan Lahan, dan Peta Evaluasi Kesesuaian Tutupan Lahan Berbasis Tata Ruang dengan Arahan Pemanfaatan Lahan Kecamatan Karangkobar.

Adapun pengolahan data dengan langkah pembobotan dan skoring pada software SIG berupa ArcView 3.3, yang memiliki kemampuaan tampilan data spasial dan data atributnya sangat membantu dalam penelitian ini.

2. Tahap Analisis Data

a. Tutupan Lahan Berbasis Tata Ruang

Analisis tutupan lahan berbasis tata ruang dilakukan secara kualitatif dari interpretasi Peta Tutupan Lahan Berbasis Tata Ruang Kecamatan Karangkobar yang merupakan hasil turunan dari Peta Tutupan Lahan Berbasis Tata Ruang Kabupaten Banjarnegara, dan dengan menggunakan analisis data spasial dan data atribut pada ArcView 3.3 dapat diperoleh bentuk-bentuk pemanfaatan lahan dan luasannya secara terperinci.

b. Arahan Pemanfaatan Lahan

Analisis arahan pemanfaatan lahan dilakukan secara kualitatif dari interpretasi Peta Arahan Pemanfaatan Lahan. Peta tersebut diperoleh dengan langkah pembobotan dan skoring yang telah diatur dalam Surat Keputusan Menteri Pertanian No. 837/KPTS/UM/1980, perincianan pada Tabel 1, dan menggunakan teknik overlay yang dimiliki SIG.

c. Evaluasi Kesesuaian Tutupan Lahan Berbasis Tata Ruang dengan Arahan Pemanfaatan Lahan Kecamatan Karangkobar

Evaluasi kesesuaian tutupan lahan berbasis tata ruang dengan arahan pemanfaatan lahan Kecamatan Karangkobar dibagi menjadi 2 yaitu sesuai dan tidak sesuai. Dengan analisis kesesuaian sebagai berikut: sesuai, jika tutupan lahan merupakan bentuk aktifitas dari arahan pemanfaatan lahan Kecamatan Karangkobar, lebih detail dijabarkan pada Tabel 2, dan tidak sesuai jika tutupan lahan merupakan bukan bentuk aktifitas dari arahan pemanfaatan lahan Kecamatan Karangkobar. 
Evaluasi Tutupan Lahan Sebagai Upaya Mengurangi Resiko Bencana Longsor Di Kecamatan Karangkobar Kabupaten

Tabel 1. Perhitungan Skor Lokasi Untuk Pemanfaatan Lahan

\begin{tabular}{|c|c|c|}
\hline Variabel & \multicolumn{2}{|c|}{ Kategori dan Bobot } \\
\hline Kemiringan Lereng (\%) & Kategori & Bobot \\
\hline $0-8$ & Datar & 20 \\
\hline $8-15$ & Landai & 40 \\
\hline $15-25$ & Agak Curam & 60 \\
\hline $25-40$ & Curam & 80 \\
\hline$>40$ & Sangat Curam & 100 \\
\hline Jenis Tanah & $\begin{array}{c}\text { Kepekaan Terhadap } \\
\text { Erosi }\end{array}$ & Bobot \\
\hline $\begin{array}{l}\text { Aluvial, Tanah Glei, Planosol, } \\
\text { Hidromorf Kelabu, Laterite Air Tanah }\end{array}$ & Tidak Peka & 15 \\
\hline Latosol & Agak Peka & 30 \\
\hline $\begin{array}{l}\text { Brown Forest Soil, Non Calcic Brown, } \\
\text { Mediteran }\end{array}$ & Kurang Peka & 45 \\
\hline $\begin{array}{l}\text { Andosol, Laterite, Grumusol, Podsol, } \\
\text { Podsolik }\end{array}$ & Peka & 60 \\
\hline Pegosol, Litosol, Organosol, Rezina & Sangat Peka & 75 \\
\hline Intensitas Hujan (mm/hari hujan) & Keterangan & Bobot \\
\hline$=<13,5$ & Sangat Rendah & 10 \\
\hline $13,6-20,7$ & Rendah & 20 \\
\hline $20,7-27,7$ & Sedang & 30 \\
\hline $27,7-34,8$ & Tinggi & 40 \\
\hline$>34,8$ & Sangat Tinggi & 50 \\
\hline \multicolumn{3}{|c|}{ Skor Peruntukan (Berdasarkan total bobot dari 3 variabel pada suatu lahan) } \\
\hline$>175$ & \multicolumn{2}{|c|}{ Kawasan Lindung } \\
\hline $125-174$ & \multicolumn{2}{|c|}{ Kawasan Fungsi Penyangga } \\
\hline$<125$ Lereng $<15 \%$ & \multicolumn{2}{|c|}{ Budidaya Tanaman Tahunan } \\
\hline$<125$ Lereng $<8 \%$ & \multicolumn{2}{|c|}{$\begin{array}{c}\text { Kawasan Tanaman Semusim dan } \\
\text { Permukiman }\end{array}$} \\
\hline
\end{tabular}

Sumber: Surat Keputusan Menteri Pertanian No. 837/KPTS/UM/1980

Tabel 2. Kesesuaian Tutupan Lahan Berbasis Tata Ruang dengan Arahan Pemanfaatan Lahan di Kecamatan Karangkobar

\begin{tabular}{|c|c|c|}
\hline Kesesuaian & Tutupan Lahan & Arahan Pemanfaatan Lahan \\
\hline \multirow{4}{*}{ Sesuai } & $\begin{array}{c}\text { Hutan Lindung, } \\
\text { Hutan Produksi Terbatas }\end{array}$ & Kawasan Lindung \\
\cline { 2 - 3 } & Hutan Produksi Terbatas & Kawasan Fungsi Penyangga \\
\cline { 2 - 3 } & Hutan Produksi Tetap & Kawasan Budidaya Tanaman \\
& Tahunan \\
\cline { 2 - 3 } & $\begin{array}{c}\text { Kebun Campur, Sawah, Tegalan, } \\
\text { Permukiman }\end{array}$ & $\begin{array}{c}\text { Kawasan Tanaman Semusim dan } \\
\end{array}$ \\
\hline
\end{tabular}

Sumber: Analisis Data, 2014 


\section{HASIL DAN PEMBAHASAN}

\section{Tutupan Lahan Berbasis Tata Ruang Kecamatan Karangkobar}

Tutupan Lahan berbasis tata ruang Kecamatan Karangkobar didominasi oleh Tegalan seluas 1622,74 hektar, tutupan lahan jenis ini ditemui tiap desa di Kecamatan Karangkobar, dengan lokasi terluas di Desa Binangun 312,15 hektar. Kemudian Kebun Campur 1071,04 hektar, sama seperti Tegalan yang mendominasi di seluruh desa yang ada di Kecamatan Karangkobar, terluas di Desa Pawedan 278,01 hektar. Selanjutnya tutupan lahan jenis Sawah Irigasi 479,16 hektar, terluas dimiliki oleh Desa Pagerpelah 154,72 hektar.

Tutupan lahan dengan jenis Hutan Produksi Terbatas 476,94 hektar, dengan persebaran terluas di Desa Gumelar 194,27 hektar. Kemudian tutupan lahan jenis Permukiman 239,50 hektar, banyak berkumpul di Desa Leksana seluas 50,21 hektar dan Hutan Lindung seluas 107,40 hektar, mendominasi di Desa Pasuruhan seluas 58,78 hektar. Tutupan lahan berbasis tata ruang Kecamatan Karangkobar menunjukkan dominasi pemanfaatan lahan untuk Kawasan Budidaya Tanaman Semusim dan Permukiman. Persebaran tutupan lahan berbasis tata ruang Kecamatan Karangkobar nampak pada Gambar 1.

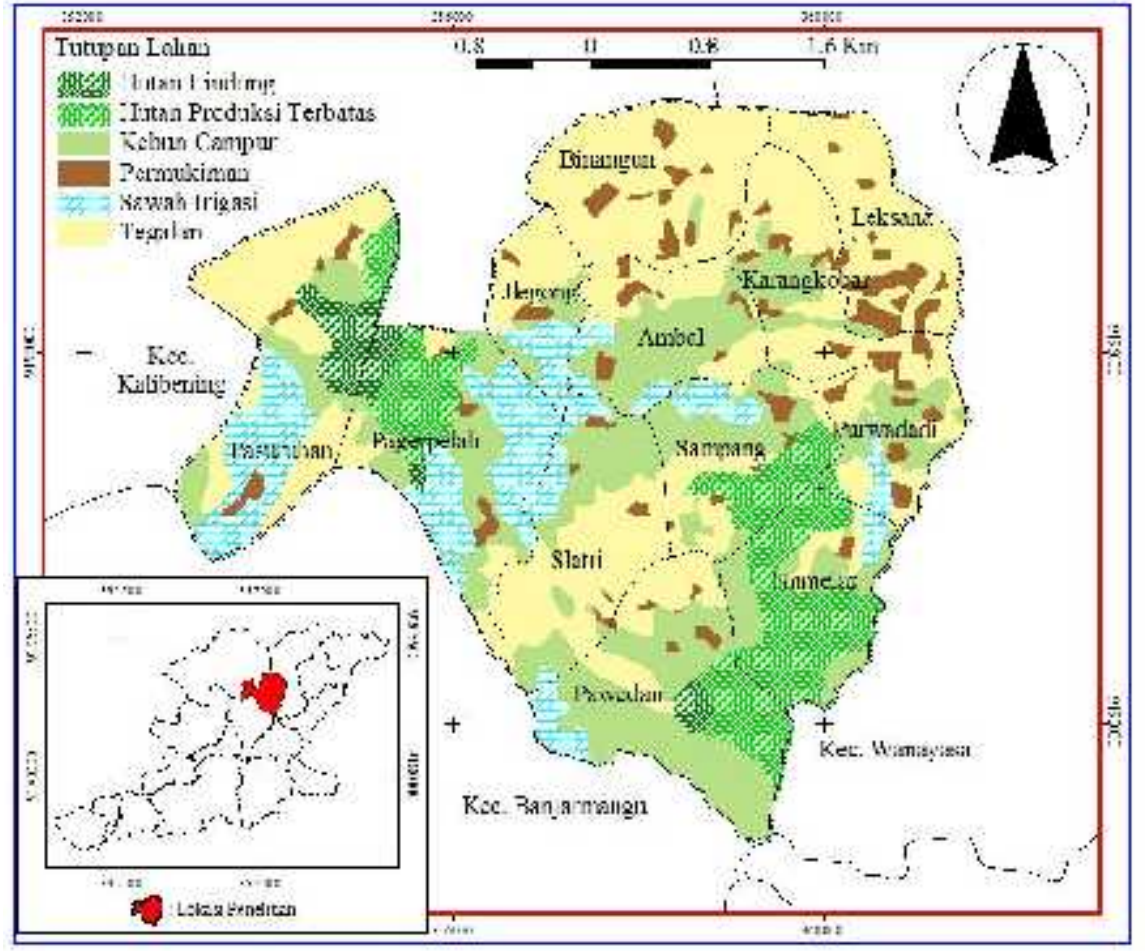

Gambar 1. Peta Tutupan Lahan Berbasis Tata Ruang Kecamatan Karangkobar

\section{Arahan Pemanfaatan Lahan Kecamatan Karangkobar}

Arahan pemanfaatan lahan yang sesuai di Kecamatan Karangkobar hanya 2 kawasan, yaitu Kawasan Lindung dan Kawasan Fungsi Penyangga. Arahan pemanfaatan lahan yang sesuai untuk Kawasan Lindung seharusnya berada di Desa Karangkobar seluas 9,66 hektar, Desa Purwadadi 18,96 hektar, Desa Pawedan 39,68 
hektar, Desa Gumelar 86,62 hektar, Desa Slatri 95,91 hektar dan Desa Sampang 108,94 hektar.

Sedangkan Kawasan Fungsi Penyangga semestinya memenuhi luas wilayah Desa Ambal, Binangun, Jlegong, Leksana, Pagerpelah, Pasuruhan. Dan Arahan pemanfaatan lahan untuk Kawasan Fungsi Penyangga menyebar pula di Desa Karangkobar dengan luas 25,63 hektar, Desa Sampang 79,75 hektar, Desa Purwadadi 115,74 hektar, Desa Gumelar 166,23 hektar, Desa Slatri 215,99 hektar dan Desa Pawedan 279,43 hektar. Persebaran arahan pemanfaatan lahan Kecamatan Karangkobar nampak pada Gambar 2.

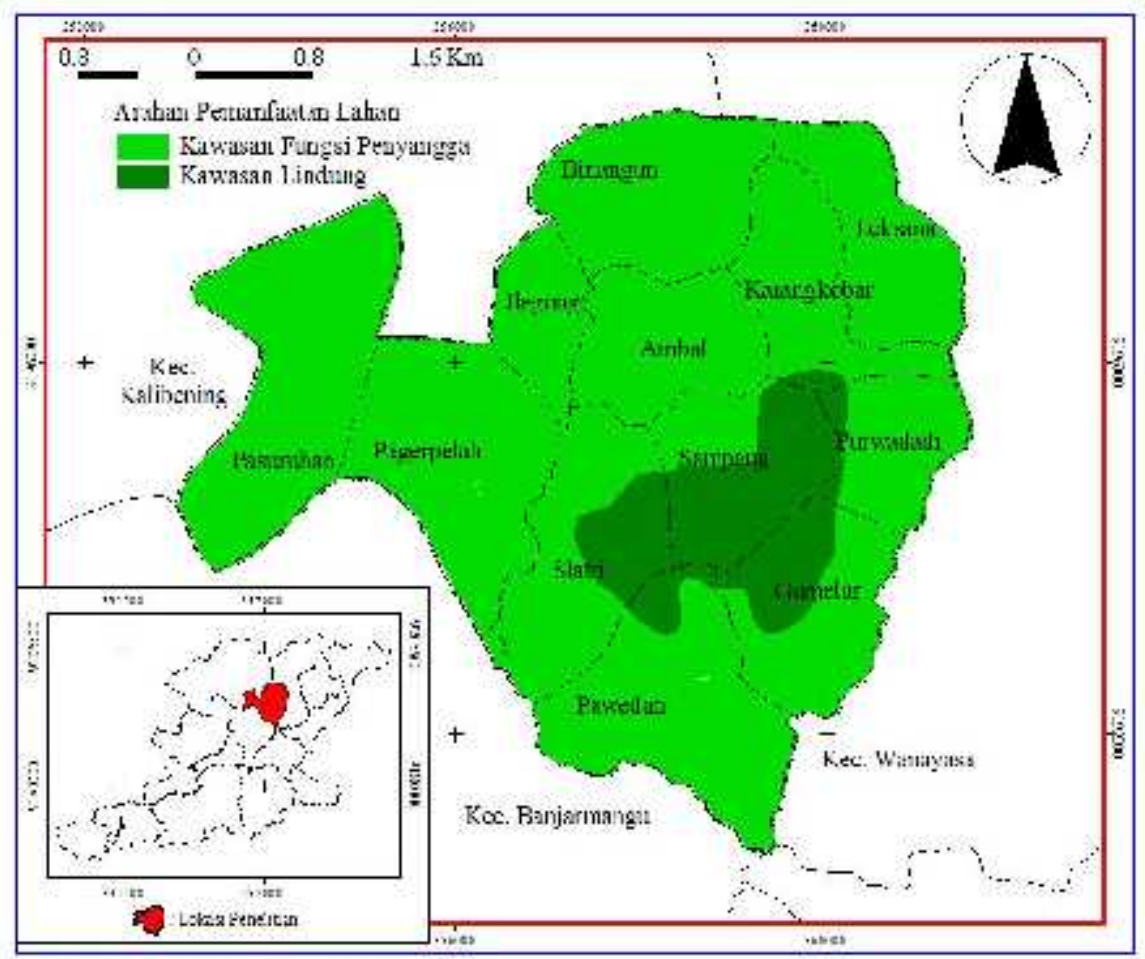

Gambar 2. Peta Arahan Pemanfaatan Lahan Kecamatan Karangkobar

\section{Evaluasi Kesesuaian Tutupan Lahan Berbasis Tata Ruang Dengan Arahan Pemanfaatan Lahan Kecamatan Karangkobar}

Kesesuaian tutupan lahan berbasis tata ruang dengan arahan pemanfaatan lahan Kecamatan Karangkobar menunjukkan 584,34 hektar tutupan lahan telah menunjukkan sesuai dengan arahan pemanfaatan lahan, menyebar di Desa Purwadadi 7,15 hektar, Desa Pasuruhan 85,09 hektar, Desa Pawedan 96,59 hektar, Desa Sampang 79,73 hektar, Desa Pagerpelah 121,52 hektar dan Desa Gumelar 194,25 hektar.

Sedangkan 3412,44 hektar tutupan lahan berbasis tata ruang lainnya menunjukkan ketidak sesuaian dengan arahan pemanfaatan lahan, meliputi Desa Pasuruhan 452,83 hektar, Desa Pawedan 374,02 hektar, Desa Pagerpelah 338,59 hektar, Desa Sampang 220,53 hektar, Desa Purwadadi 201,90 hektar, Desa Gumelar 125,31 hektar dan seluruh luas wilayah Desa Binangun 352,79 hektar, Desa Ambal 273,71 hektar, Desa Jlegong 150,38 hektar, Desa Karangkobar 263,62 hektar, Desa Leksana 277,04 hektar, Desa Slatri 381,74 hektar. Evaluasi Kesesuaian Tutupan Lahan 
Berbasis Tata Ruang dengan Arahan Pemanfaatan Lahan Kecamatan Karangkobar nampak pada Gambar 3.

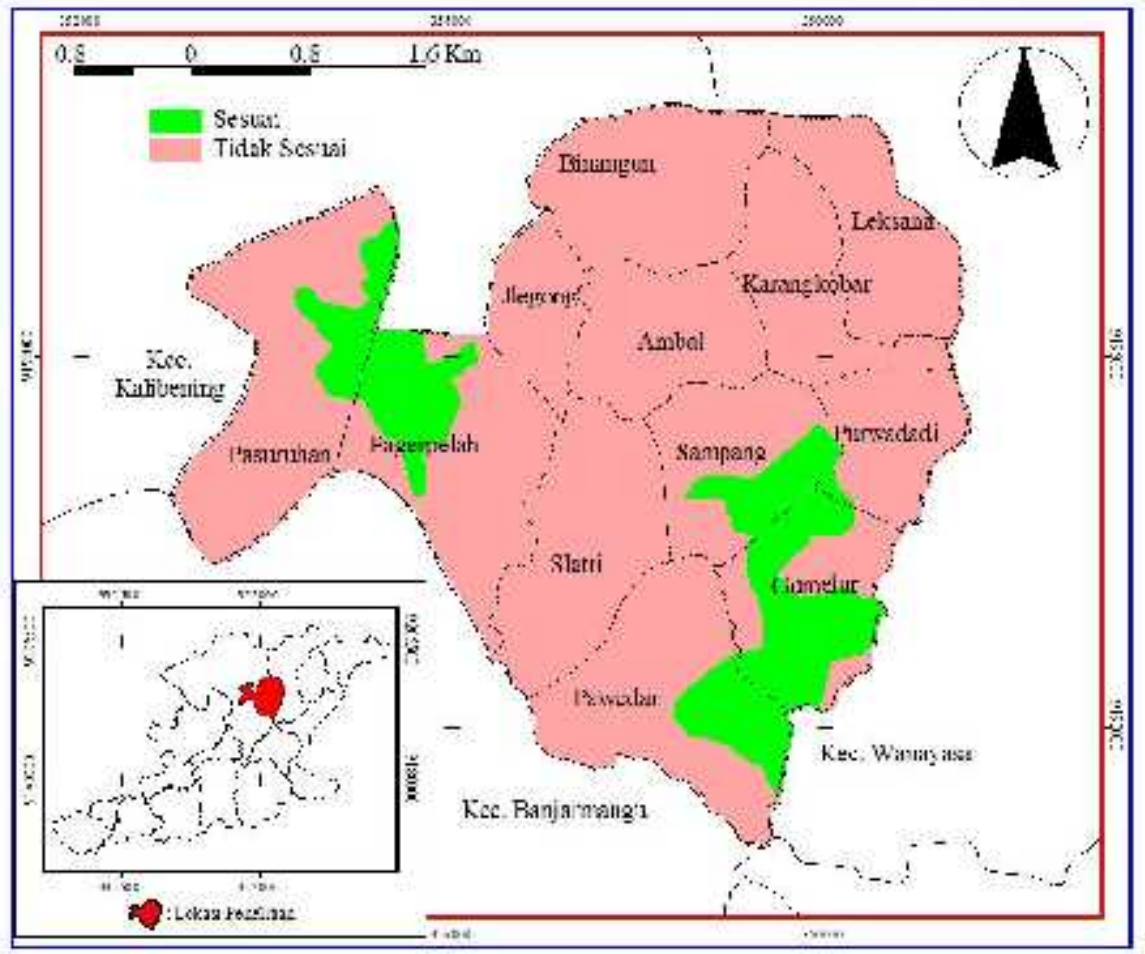

Gambar 3. Peta Evaluasi Kesesuaian Tutupan Lahan Berbasis Tata Ruang Dengan Arahan Pemanfaatan Lahan Kecamatan Karangkobar

Evaluasi kesesuaian tutupan lahan berbasis tata ruang dengan arahan pemanfaatan lahan Kecamatan Karangkobar menunjukkan bahwa 85,38\% tutupan lahan berbasis tata ruang dalam bentuk pemanfaatan budidaya tanaman semusim dan permukiman, yang sebenarnya tidak sesuai dengan arahan pemanfaatan lahan semestinya. Hanya $14,62 \%$ saja tutupan lahan berbasis tata ruang yang sesuai dengan arahan pemanfaatan lahan Kecamatan Karangkobar.

Kondisi yang demikian mengakibatkan dimensi kedepan Kecamatan Karangkobar memiliki resiko yang lebih tinggi untuk terjadinya bencana longsor. Bentuk intervensi manusia dalam pemanfaatan lahan Kecamatan Karangkobar yang diatur dalam rencana tata ruang Kabupaten Banjarnegara Tahun 2011-2031 terbukti tidak memperhatikan keberlangsungan lahan yang semestinya digunakan untuk kawasan fungsi penyangga dan kawasan lindung. Untuk itu perlu kebijakan yang ketat dalam pemanfaatan lahan di kecamatan ini, antara lain:

a. Revisi Rencana Tata Ruang khususnya rencana tutupan lahan Kecamatan Karangkobar.

b. Pada Lahan yang terbukti tidak sesuai dengan arahan pemanfaatan lahan, sangat perlu segera dilakukan konservasi untuk menjadi arahan pemanfaatan lahan yang semestinya.

c. Membatasi dengan ketat permukiman, atau sebisa mungkin melakukan relokasi permukiman pada lokasi yang memiliki resiko bencana longsor yang tinggi. 
d. Pemerintah bersama-sama dengan masyarakat setempat bekerja sama dalam mengembangkan pemanfaatan lahan sesuai arahan pemanfaatan lahan untuk menghasilkan kesejahteraan.

e. Memberikan wawasan mengenai peta bencana longsor bagi masyarakat dan menentukan lokasi aman jika terjadi bencana longsor, atau bentuk mitigasi longsor.

f. Memberikan insentif bagi perorangan masyarakat yang ikut andil menyukseskan konservasi secara tepat dan cepat, dan disinsentif bagi yang melanggar atau menghalangi dalam mengsukseskan konservasi lahan menjadi Kawasan Lindung dan Fungsi Penyangga.

Evaluasi kesesuaian tutupan lahan berbasis tata ruang dengan arahan pemanfaatan lahan tiap desa Kecamatan Karangkobar diperjelas pada rincian tabel 3 berikut ini.

Tabel 3. Evaluasi Tutupan Lahan Berbasis Tata Ruang dengan Arahan Pemanfaatan Lahan di Kecamatan Karangkobar

\begin{tabular}{|c|c|c|c|c|c|}
\hline NO & DESA & TUTUPAN LAHAN & $\begin{array}{l}\text { ARAHAN } \\
\text { LAHAN }\end{array}$ & EVALUASI & LUAS (HEKTAR) \\
\hline \multirow{4}{*}{1.} & \multirow{4}{*}{ Ambal } & Permukiman & \multirow{4}{*}{$\begin{array}{l}\text { Kawasan Fungsi } \\
\text { Penyangga }\end{array}$} & $\begin{array}{l}\text { Tidak } \\
\text { Sesuai }\end{array}$ & 19,13 \\
\hline & & Kebun Campur & & $\begin{array}{l}\text { Tidak } \\
\text { Sesuai }\end{array}$ & 137,62 \\
\hline & & Sawah Irigasi & & $\begin{array}{l}\text { Tidak } \\
\text { Sesuai }\end{array}$ & 25,02 \\
\hline & & Tegalan & & $\begin{array}{l}\text { Tidak } \\
\text { Sesuai }\end{array}$ & 91,94 \\
\hline \multirow[b]{3}{*}{2.} & \multirow[b]{3}{*}{ Binangun } & Permukiman & \multirow{3}{*}{$\begin{array}{l}\text { Kawasan Fungsi } \\
\text { Penyangga }\end{array}$} & $\begin{array}{l}\text { Tidak } \\
\text { Sesuai }\end{array}$ & 35,38 \\
\hline & & Kebun Campur & & $\begin{array}{l}\text { Tidak } \\
\text { Sesuai }\end{array}$ & 5,27 \\
\hline & & Tegalan & & $\begin{array}{l}\text { Tidak } \\
\text { Sesuai }\end{array}$ & 312,15 \\
\hline \multirow{8}{*}{3.} & \multirow{8}{*}{ Gumelar } & Kebun Campur & \multirow{3}{*}{$\begin{array}{l}\text { Kawasan } \\
\text { Lindung }\end{array}$} & $\begin{array}{l}\text { Tidak } \\
\text { Sesuai }\end{array}$ & 24,02 \\
\hline & & Tegalan & & $\begin{array}{l}\text { Tidak } \\
\text { Sesuai }\end{array}$ & 11,07 \\
\hline & & $\begin{array}{l}\text { Hutan Produksi } \\
\text { Terbatas }\end{array}$ & & Sesuai & 70,38 \\
\hline & & Permukiman & \multirow{5}{*}{$\begin{array}{l}\text { Kawasan Fungsi } \\
\text { Penyangga }\end{array}$} & $\begin{array}{l}\text { Tidak } \\
\text { Sesuai }\end{array}$ & 3,93 \\
\hline & & Kebun Campur & & $\begin{array}{l}\text { Tidak } \\
\text { Sesuai }\end{array}$ & 60,16 \\
\hline & & Sawah Irigasi & & $\begin{array}{l}\text { Tidak } \\
\text { Sesuai }\end{array}$ & 12,54 \\
\hline & & Tegalan & & $\begin{array}{l}\text { Tidak } \\
\text { Sesuai }\end{array}$ & 13,60 \\
\hline & & Hutan Produksi & & Sesuai & 123,87 \\
\hline
\end{tabular}




\begin{tabular}{|c|c|c|c|c|c|}
\hline & & Terbatas & & & \\
\hline \multirow{4}{*}{4.} & \multirow{4}{*}{ Jlegong } & Permukiman & \multirow{4}{*}{$\begin{array}{l}\text { Kawasan Fungsi } \\
\text { Penyangga }\end{array}$} & $\begin{array}{l}\text { Tidak } \\
\text { Sesuai }\end{array}$ & 8,32 \\
\hline & & Kebun Campur & & $\begin{array}{l}\text { Tidak } \\
\text { Sesuai }\end{array}$ & 28,78 \\
\hline & & Sawah Irigasi & & $\begin{array}{l}\text { Tidak } \\
\text { Sesuai }\end{array}$ & 38,19 \\
\hline & & Tegalan & & $\begin{array}{l}\text { Tidak } \\
\text { Sesuai }\end{array}$ & 75,09 \\
\hline \multirow{5}{*}{5.} & \multirow{5}{*}{ Karangkobar } & Kebun Campur & \multirow{2}{*}{$\begin{array}{l}\text { Kawasan } \\
\text { Lindung }\end{array}$} & $\begin{array}{l}\text { Tidak } \\
\text { Sesuai }\end{array}$ & 1,06 \\
\hline & & Tegalan & & $\begin{array}{l}\text { Tidak } \\
\text { Sesuai }\end{array}$ & 8,59 \\
\hline & & Permukiman & Kawasan Fungsi & $\begin{array}{l}\text { Tidak } \\
\text { Sesuai }\end{array}$ & 28,69 \\
\hline & & Kebun Campur & Penyangga & $\begin{array}{l}\text { Tidak } \\
\text { Sesuai }\end{array}$ & 63,41 \\
\hline & & Tegalan & & $\begin{array}{l}\text { Tidak } \\
\text { Sesuai }\end{array}$ & 161,87 \\
\hline \multirow[b]{3}{*}{6.} & \multirow[b]{3}{*}{ Leksana } & Permukiman & \multirow{3}{*}{$\begin{array}{l}\text { Kawasan Fungsi } \\
\text { Penyangga }\end{array}$} & $\begin{array}{l}\text { Tidak } \\
\text { Sesuai }\end{array}$ & 50,21 \\
\hline & & Kebun Campur & & $\begin{array}{l}\text { Tidak } \\
\text { Sesuai }\end{array}$ & 4,56 \\
\hline & & Tegalan & & $\begin{array}{l}\text { Tidak } \\
\text { Sesuai }\end{array}$ & 222,27 \\
\hline \multirow{6}{*}{7.} & \multirow{6}{*}{ Pagerpelah } & Permukiman & \multirow{6}{*}{$\begin{array}{l}\text { Kawasan Fungsi } \\
\text { Penyangga }\end{array}$} & $\begin{array}{l}\text { Tidak } \\
\text { Sesuai }\end{array}$ & 13,11 \\
\hline & & Kebun Campur & & $\begin{array}{l}\text { Tidak } \\
\text { Sesuai }\end{array}$ & 125,40 \\
\hline & & Sawah Irigasi & & $\begin{array}{l}\text { Tidak } \\
\text { Sesuai }\end{array}$ & 154,72 \\
\hline & & Tegalan & & $\begin{array}{l}\text { Tidak } \\
\text { Sesuai }\end{array}$ & 45,37 \\
\hline & & Hutan Lindung & & Sesuai & 30,92 \\
\hline & & $\begin{array}{l}\text { Hutan Produksi } \\
\text { Terbatas }\end{array}$ & & Sesuai & 90,61 \\
\hline \multirow{6}{*}{8.} & \multirow{6}{*}{ Pasuruhan } & Tegalan & \multirow{6}{*}{$\begin{array}{l}\text { Kawasan Fungsi } \\
\text { Penyangga }\end{array}$} & $\begin{array}{l}\text { Tidak } \\
\text { Sesuai }\end{array}$ & 229,64 \\
\hline & & Kebun Campur & & $\begin{array}{l}\text { Tidak } \\
\text { Sesuai }\end{array}$ & 74,68 \\
\hline & & Sawah Irigasi & & $\begin{array}{l}\text { Tidak } \\
\text { Sesuai }\end{array}$ & 128,44 \\
\hline & & Permukiman & & $\begin{array}{l}\text { Tidak } \\
\text { Sesuai }\end{array}$ & 20,08 \\
\hline & & Hutan Lindung & & Sesuai & 58,78 \\
\hline & & $\begin{array}{l}\text { Hutan Produksi } \\
\text { Terbatas }\end{array}$ & & Sesuai & 26,31 \\
\hline 9. & Pawedan & Permukiman & & $\begin{array}{l}\text { Tidak } \\
\text { Sesuai }\end{array}$ & 1,61 \\
\hline
\end{tabular}




\begin{tabular}{|c|c|c|c|c|c|}
\hline & & Kebun Campur & $\begin{array}{l}\text { Kawasan } \\
\text { Lindung }\end{array}$ & $\begin{array}{l}\text { Tidak } \\
\text { Sesuai }\end{array}$ & 5,36 \\
\hline & & Tegalan & & $\begin{array}{l}\text { Tidak } \\
\text { Sesuai }\end{array}$ & 32,95 \\
\hline & & Permukiman & & $\begin{array}{l}\text { Tidak } \\
\text { Sesuai }\end{array}$ & 9,05 \\
\hline & & Kebun Campur & & $\begin{array}{l}\text { Tidak } \\
\text { Sesuai }\end{array}$ & 242,01 \\
\hline & & Tegalan & $\begin{array}{l}\text { Kawasan Fungsi } \\
\text { Penyangga }\end{array}$ & $\begin{array}{l}\text { Tidak } \\
\text { Sesuai }\end{array}$ & 53,24 \\
\hline & & Sawah Irigasi & & $\begin{array}{l}\text { Tidak } \\
\text { Sesuai }\end{array}$ & 29,80 \\
\hline & & $\begin{array}{l}\text { Hutan Produksi } \\
\text { Terbatas }\end{array}$ & & Sesuai & 78,89 \\
\hline & & Hutan Lindung & & Sesuai & 17,70 \\
\hline & & Permukiman & & $\begin{array}{l}\text { Tidak } \\
\text { Sesuai }\end{array}$ & 3,84 \\
\hline & & Kebun Campur & Kawasan & $\begin{array}{l}\text { Tidak } \\
\text { Sesuai }\end{array}$ & 0,72 \\
\hline & & Tegalan & Lindung & $\begin{array}{l}\text { Tidak } \\
\text { Sesuai }\end{array}$ & 9,55 \\
\hline & & $\begin{array}{l}\text { Hutan Produksi } \\
\text { Terbatas }\end{array}$ & & Sesuai & 5,03 \\
\hline & & Permukiman & & $\begin{array}{l}\text { Tidak } \\
\text { Sesuai }\end{array}$ & 21,86 \\
\hline 10. & Purwadadi & Kebun Campur & & $\begin{array}{l}\text { Tidak } \\
\text { Sesuai }\end{array}$ & 71,00 \\
\hline & & Sawah Irigasi & Kawasan Fungsi & $\begin{array}{l}\text { Tidak } \\
\text { Sesuai }\end{array}$ & 17,99 \\
\hline & & Tegalan & Penyangga & $\begin{array}{l}\text { Tidak } \\
\text { Sesuai }\end{array}$ & 76,94 \\
\hline & & $\begin{array}{l}\text { Hutan Produksi } \\
\text { Terbatas }\end{array}$ & & Sesuai & 2,13 \\
\hline & & Permukiman & & $\begin{array}{l}\text { Tidak } \\
\text { Sesuai }\end{array}$ & 13,26 \\
\hline & & Kebun Campur & Kawasan & $\begin{array}{l}\text { Tidak } \\
\text { Sesuai }\end{array}$ & 48,32 \\
\hline & & Sawah Irigasi & Lindung & $\begin{array}{l}\text { Tidak } \\
\text { Sesuai }\end{array}$ & 1,57 \\
\hline & & Tegalan & & $\begin{array}{l}\text { Tidak } \\
\text { Sesuai }\end{array}$ & 69,21 \\
\hline 11. & Sampang & $\begin{array}{l}\text { Hutan Produksi } \\
\text { Terbatas }\end{array}$ & & Sesuai & 79,36 \\
\hline & & Kebun Campur & & $\begin{array}{l}\text { Tidak } \\
\text { Sesuai }\end{array}$ & 51,46 \\
\hline & & Sawah Irigasi & $\begin{array}{l}\text { Kawasan Fungsi } \\
\text { Penyangga }\end{array}$ & $\begin{array}{l}\text { Tidak } \\
\text { Sesuai }\end{array}$ & 28,78 \\
\hline & & Tegalan & & $\begin{array}{l}\text { Tidak } \\
\text { Sesuai }\end{array}$ & 7,92 \\
\hline
\end{tabular}




\begin{tabular}{|c|c|c|c|c|c|}
\hline & & $\begin{array}{l}\text { Hutan Produksi } \\
\text { Terbatas }\end{array}$ & & Sesuai & 0,37 \\
\hline \multirow{7}{*}{12.} & \multirow{7}{*}{ Slatri } & Permukiman & \multirow{3}{*}{$\begin{array}{l}\text { Kawasan } \\
\text { Lindung }\end{array}$} & $\begin{array}{l}\text { Tidak } \\
\text { Sesuai }\end{array}$ & 3,32 \\
\hline & & Kebun Campur & & $\begin{array}{l}\text { Tidak } \\
\text { Sesuai }\end{array}$ & 9,35 \\
\hline & & Tegalan & & $\begin{array}{l}\text { Tidak } \\
\text { Sesuai }\end{array}$ & 86,53 \\
\hline & & Permukiman & \multirow{4}{*}{$\begin{array}{l}\text { Kawasan Fungsi } \\
\text { Penyangga }\end{array}$} & $\begin{array}{l}\text { Tidak } \\
\text { Sesuai }\end{array}$ & 7,73 \\
\hline & & Kebun Campur & & $\begin{array}{l}\text { Tidak } \\
\text { Sesuai }\end{array}$ & 117,87 \\
\hline & & Sawah Irigasi & & $\begin{array}{l}\text { Tidak } \\
\text { Sesuai }\end{array}$ & 42,12 \\
\hline & & Tegalan & & $\begin{array}{l}\text { Tidak } \\
\text { Sesuai }\end{array}$ & 114,82 \\
\hline
\end{tabular}

Sumber: Analisis Data, 2014

\section{KESIMPULAN DAN SARAN}

\section{Kesimpulan}

a. Tutupan lahan Berbasis Tata Ruang Kecamatan Karangkobar menunjukkan dominasi pemanfaatan lahan untuk Kawasan Budidaya Tanaman Semusim dan Permukiman.

b. Arahan pemanfaatan lahan yang sesuai di Kecamatan Karangkobar hanya 2 kawasan, yaitu Kawasan Lindung dan Kawasan Fungsi Penyangga.

c. Evaluasi kesesuaian tutupan lahan berbasis tata ruang dengan arahan pemanfaatan lahan Kecamatan Karangkobar menunjukkan 584,34 hektar sesuai, dan 3412,44 hektar tidak sesuai.

\section{Saran}

Melihat hasil evaluasi kesesuaian tutupan lahan berbasis tata ruang dengan arahan pemanfaatan lahan, maka sangat dibutuhkan revisi tata ruang khususnya pengaturan mengenai tutupan lahan. Dan perlu tindakan yang konservasi sesuai arahan pemanfaatan lahan dengan langkah cepat dan tepat untuk mengurangi resiko bencana longsor di masa yang akan datang di Kecamatan Karangkobar. Tindakan ini tentunya yang dapat disepakati bersama antara Pemerintah dan masyarakat setempat, yang disesuaikan dengan Carring Capacity wilayah untuk memperoleh kesejahteraan yang optimal.

\section{DAFTAR PUSTAKA}

Ariati, Toeti. 2012. Akankah Proses Penataan Ruang Berakhir?. Buletin Tata Ruang. MaretApril 2012. Badan Koordinasi Penataan Ruang Nasional.

Iskandar. 2011. Aktualisasi Prinsip Hukum Pelestarian Fungsi Lingkungan Hidup dalam Kebijakan Perubahan Peruntukan, Fungsi dan Penggunaan Kawasan Hutan. Jurnal Dinamika Hutan. Vol. 11 No. 3 September 2011. 
Evaluasi Tutupan Lahan Sebagai Upaya Mengurangi Resiko Bencana Longsor Di Kecamatan Karangkobar Kabupaten Banjarnegara

Jariyah, N.A dan Pramono, I. B. 2013. Kerentanan Sosial Ekonomi dan Biofisik di DAS Serayu: Collaborative Management. Jurnal Penelitian Sosial dan Ekonomi Kehutanan. Vol. 10 No. 3 September 2013. Hal 141-156.

Lahamendu, Verry dan Kustiwan, I. 2013. Evaluasi Pemanfaatan lahan Berbasis Tata Ruang Wilayah di Pulau Bunaken, Manado. Jurnal Perencanaan Wilayah dan Kota B SAPPK V2N3. Halaman 809-814.

Riani, Maeri., dkk. 2013. Pemetaan Kondisi Tanah dan Vegetasi Sebagai Upaya Mengurangi Terjadinya Bencana Gerakan Tanah di Desa Rahtawu Kecamatan Gebog Kabupaten Kudus. Prosiding Seminar Nasional Pengelolaan Sumberdaya Alam dan Lingkungan. Halaman 283-288.

Suci, Ajeng DYP. 2009. Arahan Fungsi Pemanfaatan Lahan di Kabupaten Wonogiri. Tugas Akhir. Universitas Diponegoro. 